\title{
Checklist and status of the amphibians and reptiles of Essex County, Ontario: a 35 year update
}

\author{
Jonathan D. Choquette ${ }^{1,2, ~}{ }^{*}$ and Eric A. Jolin ${ }^{3}$ \\ ${ }^{1}$ SCC Ecological, P.O. Box 221 Station A, Windsor, Ontario N9A 6K1 Canada \\ ${ }^{2}$ Current address: Wildlife Preservation Canada, 5420 Highway 6 North, Guelph, Ontario N1H 6J2 Canada \\ ${ }^{3}$ Wildlife Preservation Canada, 5420 Highway 6 North, Guelph, Ontario N1H 6J2 Canada \\ ${ }^{*}$ Corresponding author: jchoquette@wildlifepreservation.ca
}

Choquette, J.D., and E.A. Jolin. 2018. Checklist and status of the amphibians and reptiles of Essex County, Ontario: a 35 year update. Canadian Field-Naturalist 132(2): 176-190. https://doi.org/10.22621/cfn.v132i2.2053

\begin{abstract}
Essex County, Ontario, supports a diverse assemblage of Canadian herpetofauna. It is home to the only Canadian populations of three species/subspecies and contains two of Canada's 11 Important Amphibian and Reptile Areas. A checklist and status assessment of the herpetofauna of Essex County was previously compiled in 1983. Changes to natural habitats and an increase in monitoring efforts (e.g., citizen science) over the past 35 years warrant an updated assessment of herpetofaunal status. The county was subdivided using a $10 \times 10 \mathrm{~km}$ grid overlay, and recent observations (1997-2016) submitted to provincial databases were tabulated for each grid square. We compared current status' of herpetofauna in Essex County to those of the 1983 study using a similar classification scheme of 'extirpated from Essex' (EE; no recent observations) and 'rare in Essex' (RE; distribution $\leq 5$ squares). We found that 11 species declined in status. The majority of reptiles and amphibians (62\%) that historically occurred in Essex County are now either EE (31\%) or RE (31\%) and almost half (45\%) of the 29 extant species/subspecies are RE. A large proportion of salamanders and squamates are EE or RE ( $86 \%$ and $65 \%$, respectively). Amount of natural area and sampling effort were important variables describing patterns of observed herpetofaunal species/subspecies richness, and observed richness was highest along the western and southern edges of the mainland (16-19 species). To prevent future extirpations, recovery efforts in Essex County should occur across multiple locations and target RE species.
\end{abstract}

Key words: Essex County; herpetofauna checklist; species status assessment; reptiles and amphibians; species richness; habitat loss; citizen science; Pelee Island; Ojibway Prairie Complex; endangered species

\section{Introduction}

Essex County is within Canada's Carolinian zone, an area with the greatest diversity of flora and fauna and one of the highest concentrations of globally rare species in all of Canada (ERCA 2002; Jalava et al. 2009). The county is very important to Canadian herpetofauna, in particular, as it contains the only Canadian populations of three species/subspecies (Blue Racer [Coluber constrictor foxii], Lake Erie Watersnake [Nerodia sipedon insularum], and Small-mouthed Salamander [Ambystoma texanum]), the only Canadian location of one extirpated species (Blanchard's Cricket Frog [Acris blanchardi]), and contains two of the 11 Important Amphibian and Reptile Areas in Canada (CHS 2017).

The first comprehensive checklist and status assessment of the herpetofauna of Essex County was compiled in the early 1980s as part of a detailed study of the Environmentally Significant Areas of the county (Oldham 1983, 1984a,b). This work provided a preliminary detailed account of each species/subspecies known to inhabit Essex County at that time, complete with historical observations. The work included results of herpetofaunal surveys at Point Pelee National Park (PPNP), Pelee Island, and Ojibway Prairie Complex (OPC), with supporting data derived from local naturalist's observations, museum collections, and the author's own extensive field work in the region (Oldham 1983).
Since that time, documentation of native herpetofauna has increased dramatically in Ontario and become more sophisticated. For example, in 1984 the Ontario Herpetofaunal Summary (OHS), a citizen science initiative, officially began its first year (Pulfer 2014). Annual reports detailing observation records were developed from 1984 to 1986 (Oldham and Sutherland 1986; Oldham 1988; Weller and Oldham 1988), mostly out of the Essex Region Conservation Authority (ERCA) office in Essex, Ontario. In 2009, Ontario Nature developed the Ontario Reptile and Amphibian Atlas (ORAA) by incorporating the OHS data, expanding herpetofaunal monitoring in the province, and increasing the number of observations for areas previously lacking data (Ontario Nature 2017). With continuing technological development, the submission, management, and display of observation records have advanced. For example, the ORAA has now logged over 3000 volunteer participants submitting over 350000 observations (Ontario Nature 2015). Unfortunately, an increase in monitoring effort has been met with a decrease in availability and quality of reptile and amphibian habitat as urbanisation and agricultural activities intensify. For example, 78 ha of natural area were removed from within the Town of LaSalle for housing developments between 1986 and 1996 (Town of LaSalle 2016). At the turn of this century, $97 \%$ of wetlands and $95 \%$ of original forest cover 
in Essex County had been lost, leaving the natural landscape in a highly degraded and fragmented state (ERCA 2002). Drastic changes in both the landscape as well as monitoring efforts over the last three decades warrant an updated assessment of the current herpetofauna of Essex County and its collective status.

Our goal was to provide an updated checklist and report on the status of the herpetofauna of Essex County since it was last assessed 35 years ago. Our questions were: 1) What is the current occupancy and distribution of herpetofauna in Essex County? 2) What is the trend in status of herpetofauna in Essex County over the last 35 years? and 3) In which areas of Essex County have the greatest number of herpetofaunal species/subspecies been reported?

\section{Methods}

We confined our study to the geographic boundary of the County of Essex $\left(42.167^{\circ} \mathrm{N}, 82.783^{\circ} \mathrm{W}\right)$, which lies within the Carolinian Zone of southwestern Ontario. We subdivided the area using the same $10 \times 10 \mathrm{~km}$ grid overlay used by the OHS and ORAA (Figure 1). Grid squares included those that contained landmass or islands (or a portion thereof) and at least one 'recent' reptile or amphibian observation $(n=33)$. Five potential grid squares were not included in the study as they either contained a portion of landmass/islands but no recent observations, or had recent observations but consisted entirely of open water. Current occupancy and distribution of herpetofauna in Essex County, in addition to species/subspecies richness per grid square, was determined primarily from observation records that were submitted to the ORAA within the previous 20 years $(1997-2016 ; n=4226)$ and available online (Ontario Nature 2017; records from other provincial or national databases were not included). Data were retrieved from the ORAA in winter 2017. Observation records $(n=9)$ for two species of turtle (Eastern Spiny Softshell [Apalone spinifera spinifera] and Spotted Turtle [Clemmys guttata]) were retrieved directly from the Natural Heritage Information Centre (NHIC 2017) because records for these species are not displayed by the ORAA. Additional resources were used to support regional status assessments as required (e.g., Committee on the Status of Endangered Wildlife in Canada [COSEWIC] and Committee on the Status of Endangered Wildlife in Ontario [COSSARO] status reports, academic journal articles, and books). All observations made between 1997 and 2016 were considered 'recent' and those made prior to 1997 were considered 'historical'.

The total number of $10 \times 10 \mathrm{~km}$ squares with at least one recent observation was tallied for each species/ subspecies. We classified species/subspecies with recent observations from $\leq 5$ squares $(\leq 15 \%)$ as rare in Essex County (RE), similarly to Oldham (1983). In almost all cases, we classified a species as extirpated from Essex County (EE) if no verified observations were submitted in the past 20 years and if its current status was subjected to additional scrutiny from outside experts (e.g., species status reports, published accounts). A change in status from RE to EE does not necessarily imply a species became extirpated since the previous countylevel status assessment. An extirpation event may have actually occurred prior to the 1980s; however, we argue that sufficient time has now passed and/or new studies have occurred to presume that a given species has become locally extirpated. Amphibians and reptiles that were not classified as RE or EE were recently reported from $>5$ squares $(>15 \%)$ and therefore considered widespread.

The number of recent ORAA and NHIC observation records submitted from each $10 \times 10 \mathrm{~km}$ grid square was tallied and displayed in a graduated map using natural breaks (jenks) in a geographic information system (GIS; ArcGIS 9.1, Esri, Redlands, California, USA; Figure 2). These data were used to summarize the number of herpetofauna species/subspecies reported within each $10 \times 10 \mathrm{~km}$ grid square (i.e., observed richness). Observed richness was displayed in a graduated map using manual breaks in a GIS (Figure 3). Finally, the amount of natural area (i.e., land that has not been converted to agricultural, industrial, urban, or residential uses) present within each $10 \times 10 \mathrm{~km}$ grid square was mapped by merging five distinct data layers (Table 1; we estimated 5.9\% natural area remaining in Essex County, which is very similar to the $6.5 \%$ natural area estimated by ERCA [2002]). A Dissolve function was performed on the resultant natural area merged file to eliminate overlapping boundaries within each polygon. The Explode feature was used to separate the resultant natural area multipart feature into separate polygons. All polygons that occurred across multiple grid squares were then split along the intersecting grid line. In order to select polygons of natural areas in each individual grid square, the Select by Location feature was used. Summary statistics for the selected grid square were then obtained using the attribute table, with the sum representing hectares of natural area in the selected square. These data were then displayed in a graduated map using manual breaks in a GIS (Figure 4). We used linear regression in Microsoft Excel 2010 (version 14. 0.7190.5000, Microsoft Corporation, Redmond, Washington, USA) to predict the number of herpetofauna species/subspecies reported per square (dependent variable) based on amount of natural area per square (independent variable). Due to a small sample size we did not account for the impact of spatial autocorrelation on species richness.

\section{Results}

\section{Widespread herpetofauna of Essex County}

Sixteen species (seven amphibians, nine reptiles) are widespread in Essex County based on recent observations within six or more grid squares (Table 2). Six species of anurans that were previously considered wide- 


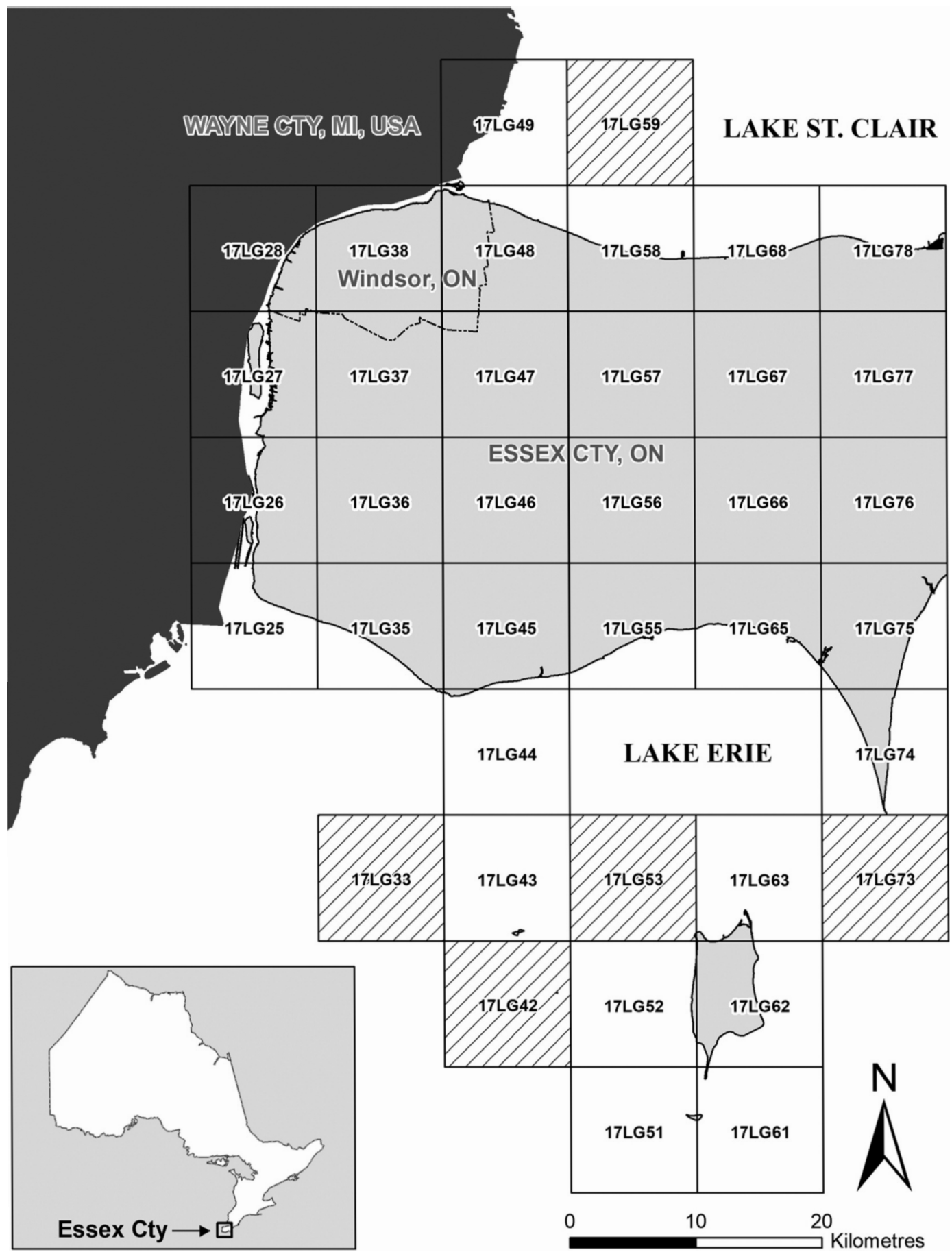

Figure 1. Map of Essex County, Ontario, showing $10 \times 10 \mathrm{~km}$ grid overlay. Grid square labels correspond with those used by Ontario Nature (2018), and hatched grid squares were not included in the study. 


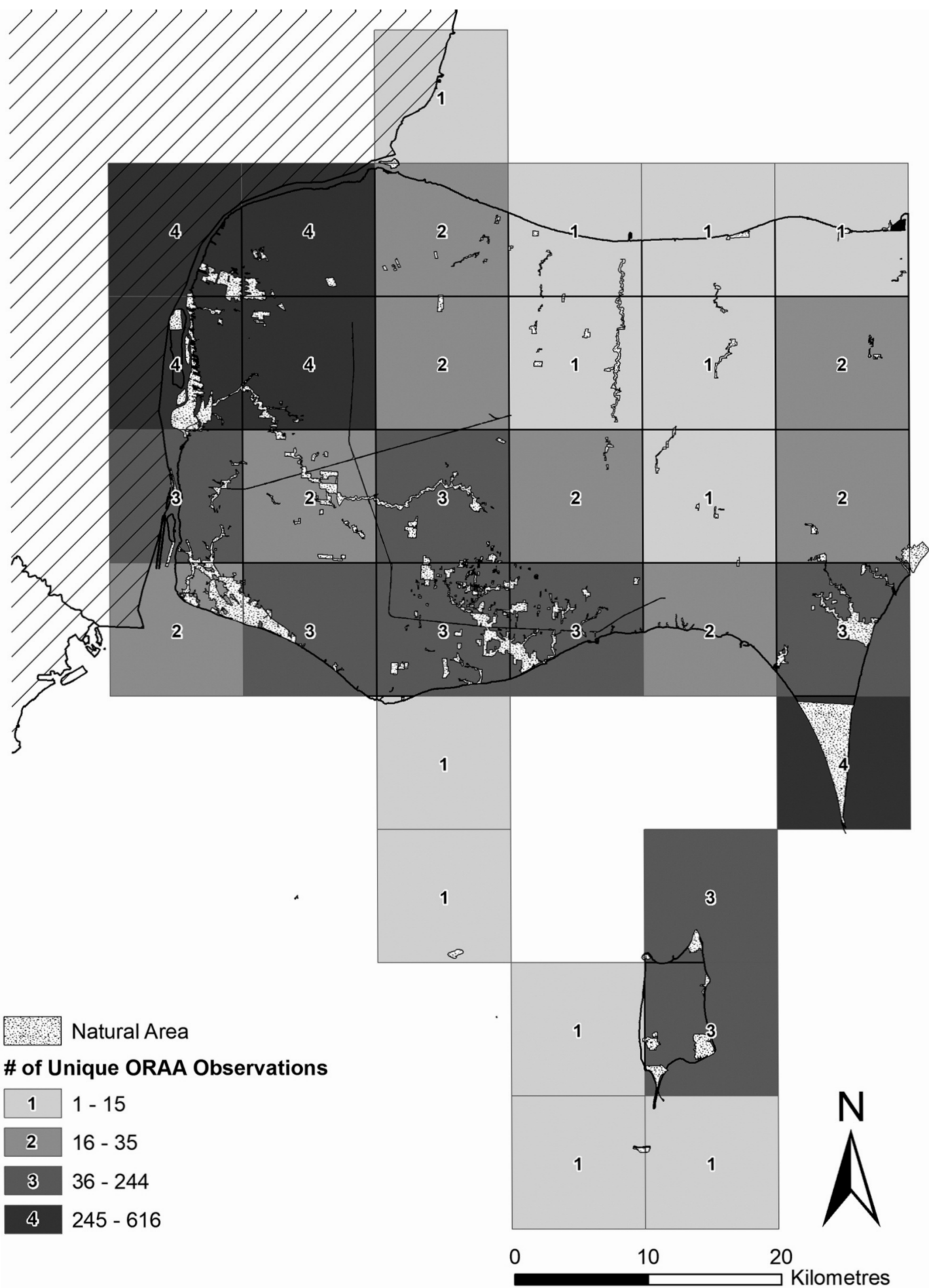

FigURE 2. Number of recent reptile and amphibian observations submitted to the Ontario Reptile and Amphibian Atlas (ORAA) per grid square. See Table 1 for description of natural area. 


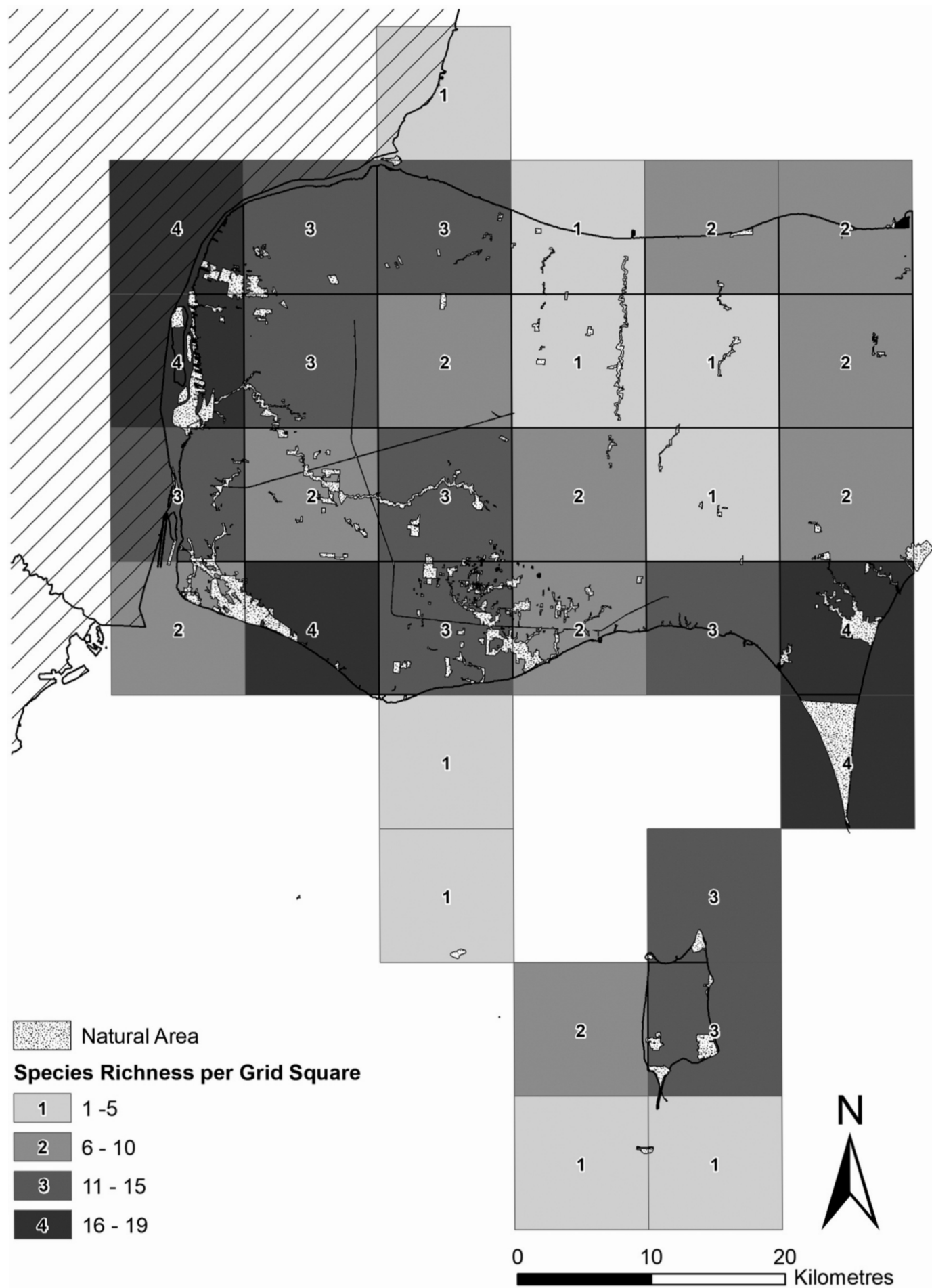

FigURE 3. Observed herpetofaunal species/subspecies richness per grid square in Essex County, Ontario. See Table 1 for description of natural area. 
TABLE 1. Data layers merged in a geographic information system to create a 'natural area' shapefile, which was subsequently used to estimate amount of 'natural area' within each $10 \times 10 \mathrm{~km}$ grid square in Essex County, Ontario. Boundaries for all ERCA (Essex Region Conservation Authority) layers are approximate, subject to verification by ERCA and subject to change (copyrighted by ERCA: 1983, 1994, 2008, and 2016). LIO = Land Information Ontario.

\begin{tabular}{llll}
\hline \hline Data Layer & Source & Year & \multicolumn{1}{c}{ Description } \\
\hline Environmentally Significant Areas & ERCA & 1983,1994 & Refer to Oldham (1983) \\
Significant Valleylands & ERCA & 2008 & Refer to Government of Ontario (2005) \\
ERCA Lands & ERCA & 2016 & Lands that are owned or managed by ERCA \\
Areas of Natural and Scientific Interest & LIO & 2014 & Refer to Government of Ontario (2005) \\
Provincially Significant Wetlands & LIO & 2006 & Refer to Government of Ontario (2005) \\
\hline \hline
\end{tabular}

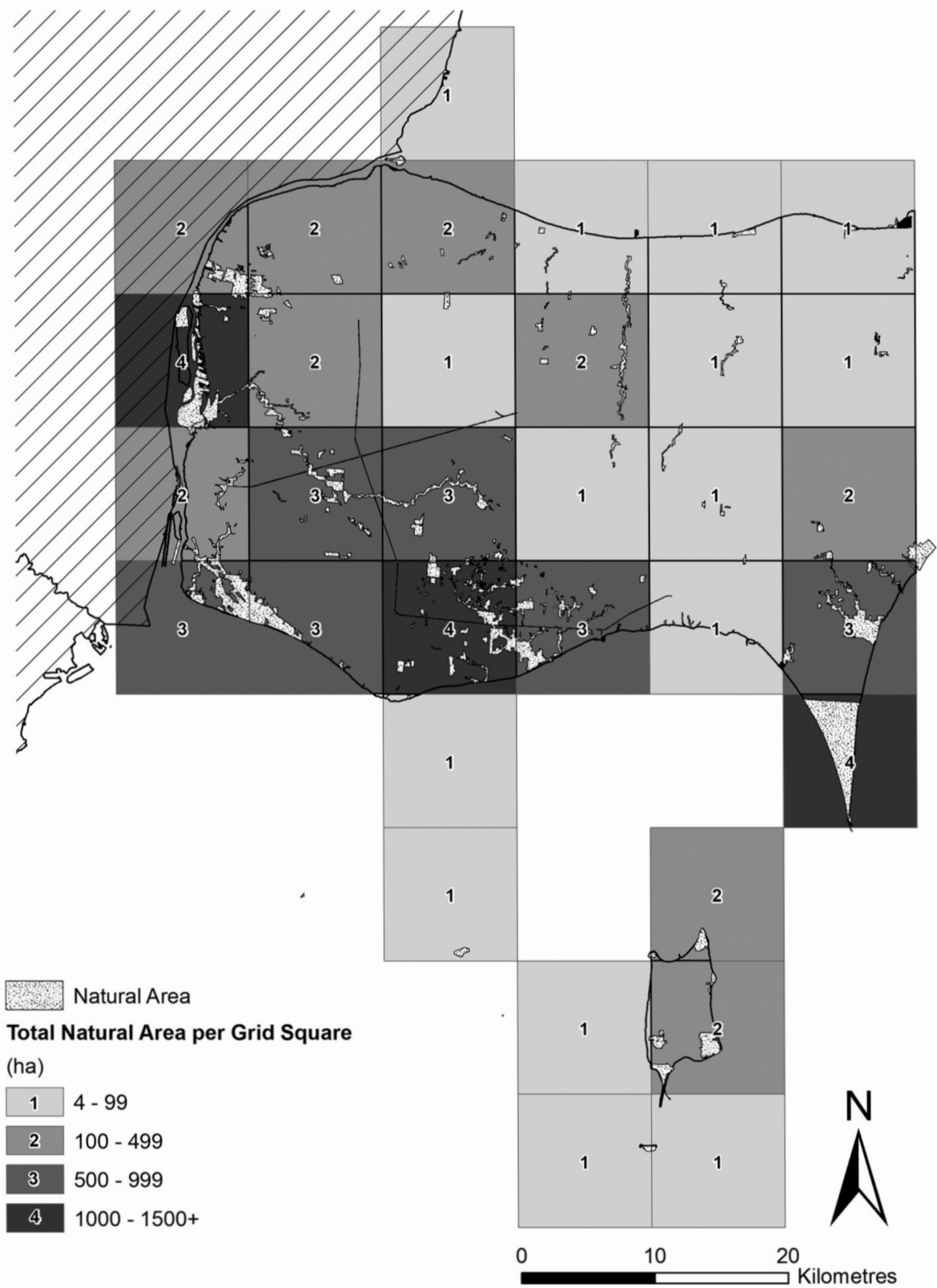

Figure 4. Amount of natural area (ha) per grid square in Essex County, Ontario. See Table 1 for description of natural area. 


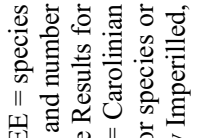

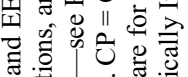

$>i$

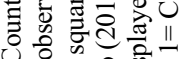

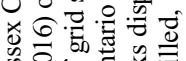

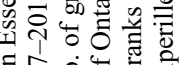

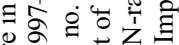

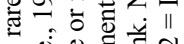

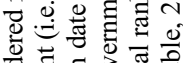

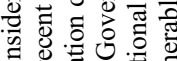

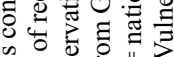

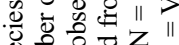

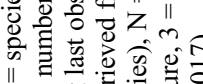

된

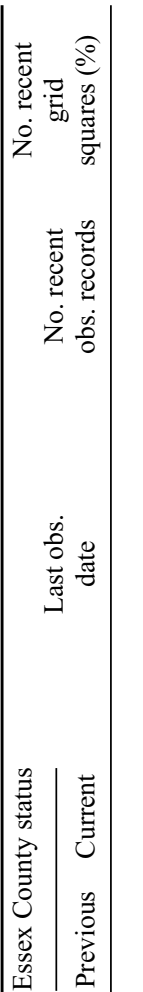

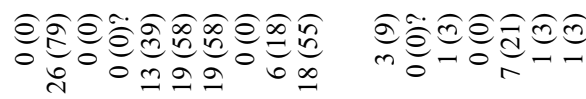

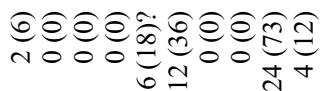

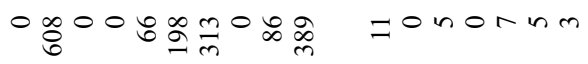

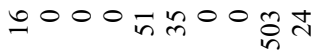

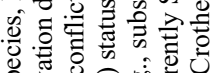

की

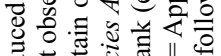

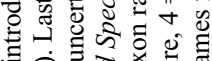

॥

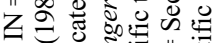

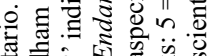

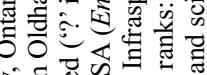

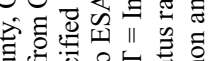

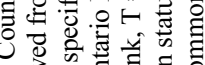

$\times$ के

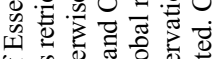

प色

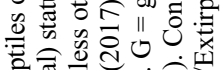

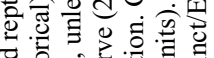

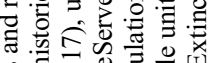

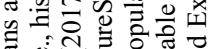

类

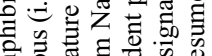

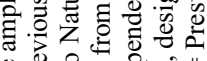

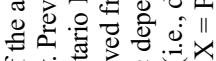

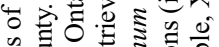

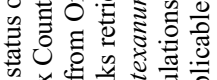

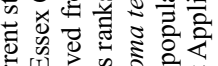

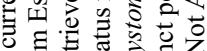

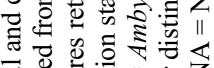

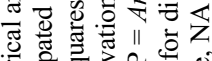

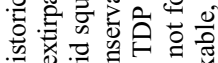

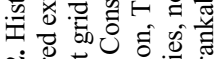

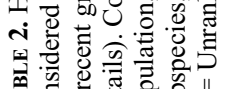

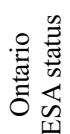

䨔

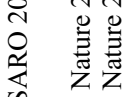

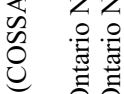

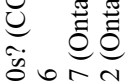

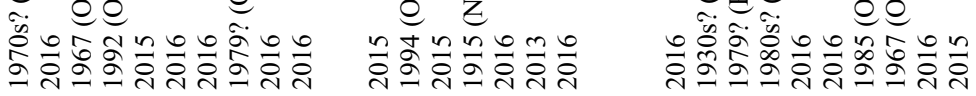

$\frac{\infty}{\tilde{c}}$

仓ิ

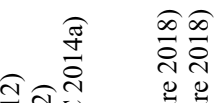

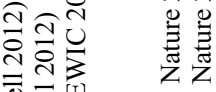

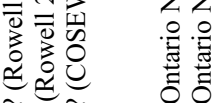

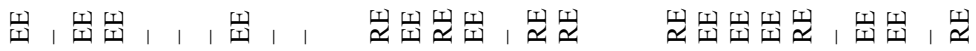

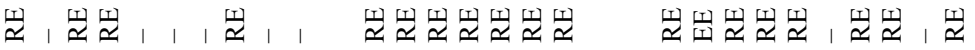

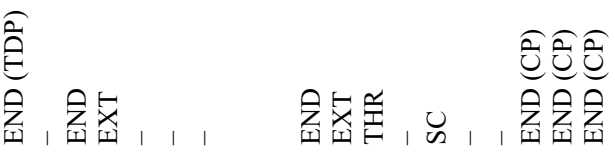

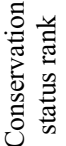

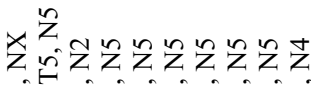

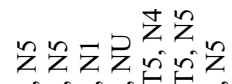

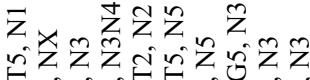

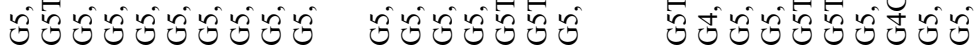
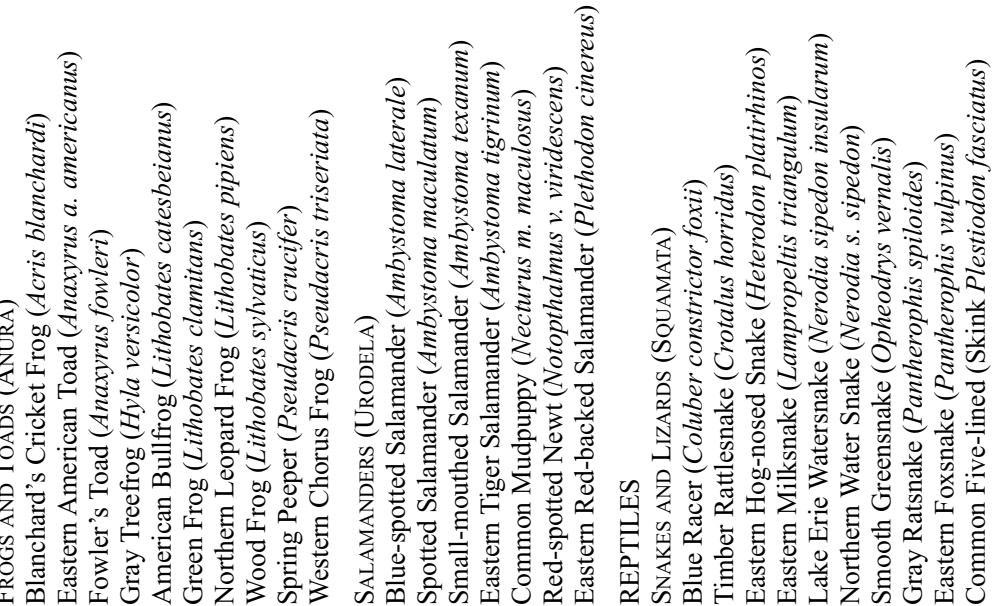


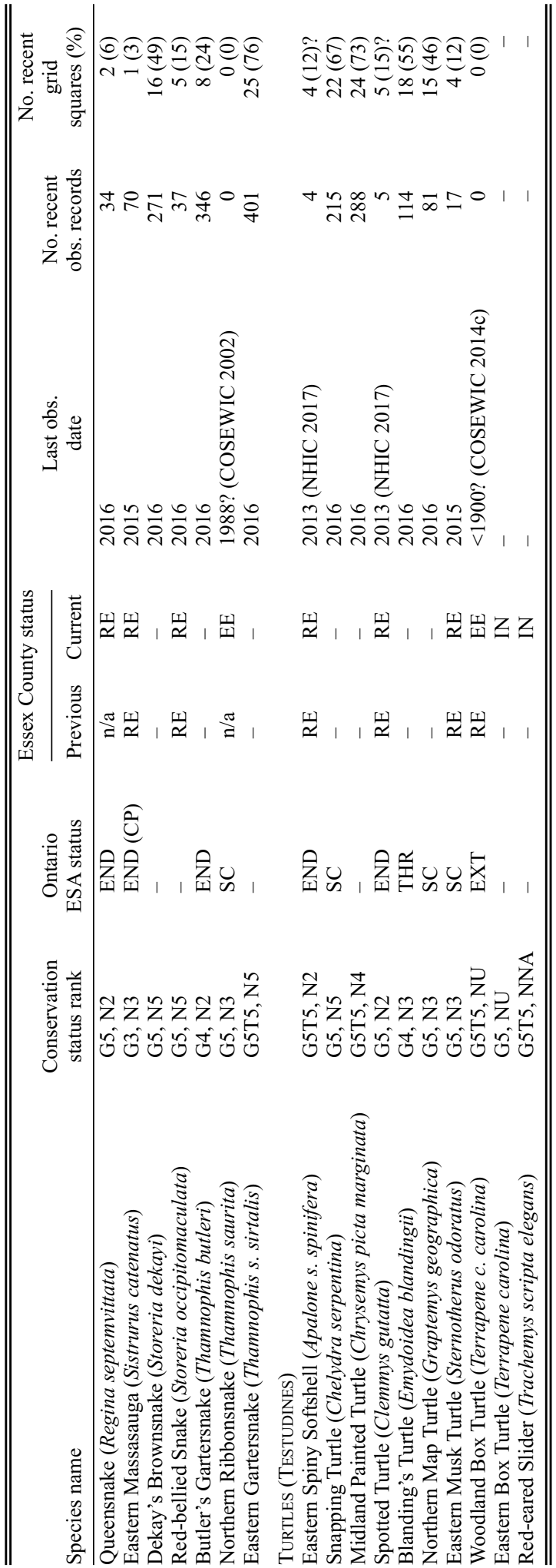


spread remain widespread today (reported from 6-26 squares [18-79\%]; Table 2), whereas one salamander that was previously considered RE is now considered widespread based on recent observations from seven squares $(21 \%)$ and new research on local abundance and distribution (Detroit River: Craig et al. 2015). Five species of snakes are widespread in Essex County, despite two of these being Species at Risk (SAR) in Ontario (reported from 8-25 squares [24-75\%]; Table 2). None were previously considered RE. Finally, four turtle species are considered widespread locally, three of which are SAR and none of which were previously classified RE (reported from 15-23 squares [46-70\%]).

\section{Rare and extirpated herpetofauna of Essex County}

We classified 13 species/subspecies as rare in Essex County (RE; four salamanders, six squamates, and three turtles; Table 2) and an additional 13 species as extirpated from Essex County (EE; four anurans, two salamanders, six squamates, and one turtle; Table 2). A relatively large proportion of salamanders $(86 \%)$ and squamates $(65 \%)$ are either extirpated (EE) or limited in distribution (RE), compared to turtles $(50 \% \mathrm{EE} / \mathrm{RE})$ or anurans ( $40 \% \mathrm{EE} / \mathrm{RE}$; Table 2). Details regarding changes to Essex County status, questionable last observation dates, and questionable number of recent squares are provided below (in order of taxonomic group).

BLANChARD's CRICKet Frog (EE): Previously RE based on call records from Pelee Island and other locations. COSEWIC (2011) assessed the species as Endangered based on unconfirmed reports from Pelee Island as recently as 1997 and the "miniscule" chance that a very small population persists. Regardless, it has been considered extirpated from Ontario (Hecnar and Hecnar 2005; COSSARO 2011a; Ontario 2018) and we consider it EE.

FOWLER's TOAD (Anaxyrus fowleri; EE): Previously $\mathrm{RE}$ based on the possibility of it persisting undetected at one or two locations in Essex County (e.g., Big Creek sub-watershed), despite being considered extirpated from PPNP and Pelee Island. We now consider it EE based on a lack of observations in 50 years and expert opinion (COSEWIC 2010a).

Gray Treefrog (Hyla versicolor; EE): Previously $\mathrm{RE}$ based on observations from Pelee Island. Additional historical sightings were reported from Windsor (EL 1976) and the PPNP area (Hecnar and Hecnar 2004; Ontario Nature 2017). We now consider the species EE based on expert opinion (Pelee Island: King et al. 1997; PPNP: Hecnar and Hecnar 2004), and a 25 year absence of records despite recent herpetofaunal surveys at historical locations (COSEWIC 2010b; Gardner-Costa et al. 2013) and 20 years of county-wide amphibian call surveys (Tozer 2016). We presume recent observations of single individuals from three disjunct squares (R. Jones unpubl. data) are vagrants (e.g., via nursery stock: Livo et al.1998) as opposed to members of res- ident breeding populations (following King et al. 1997; IUCN 2012).

WoOD Frog (Lithobates sylvaticus; EE): Previously $\mathrm{RE}$ based on unverified records from OPC and four dispersed conservation areas. Verified historical (or recent) records of this species are absent for the county (e.g., King et al. 1997; Hecnar and Hecnar 2004; Tozer 2016; Ontario Nature 2017). Regardless, its confirmed current or historical presence in all adjacent counties (i.e., Chatham-Kent [Ontario Nature 2017], Wayne [MIHerp Atlas 2017], and Erie/Ottawa [King et al. 1997]), implies a contiguous historical range that included Essex County.

Spotted Salamander (Ambystoma maculatum; EE): Previously RE based on records from only two private woodlots in the Hillman Creek sub-watershed. No recent records exist, although it may have escaped detection on private lands. Regardless, we presume this species to be EE based on a high number of recently submitted observations (Figure 2) from the sub-watershed with historical records (i.e., 17LG75 in Figure 1) coupled with a lack of detection.

EASTERn Tiger Salamander (Ambystoma tigrinum; EE): Previously RE based on presumed presence at Pelee Island and extirpation from PPNP. Authorities now suggest that the historical presence of this species in Ontario is based entirely on a single accepted specimen reportedly collected from PPNP in 1915 (Hecnar and Hecnar 2005; Ngo et al. 2009).

Timber RattLesnake (Crotalus horridus; EE): Previously $\mathrm{EE}$ based on historical observations from Pelee Island (the lone 1918 sighting from PPNP was presumed to be a vagrant from the western Lake Erie Islands). Although some authors consider the historical Pelee Island records to be questionable (King et al. 1997) or invalid (Environment Canada 2010), others (following detailed assessments) conclude that there is sufficient evidence of its former presence on Pelee Island (COSEWIC 2001; COSSARO 2011b; Rowell 2012).

EASTERN HoG-NOSED SNAKE (Heterodon platirhinos; EE): Previously RE based on records from two locations (OPC and PPNP; see Dance and Campbell 1981) and its presumed extirpation from Pelee Island. We now consider it EE based on a lack of recent observations (one 2001 observation record from Pelee Island is presumed to be erroneous) and expert opinion (King et al. 1997; Hecnar and Hecnar 2004; COSEWIC 2007; Rowell 2012).

EASTERN MILKSNAKE (Lampropeltis triangulum; EE): Previously RE based on observations from the Cedar Creek and Big Creek sub-watersheds and presumed extirpations from PPNP and Pelee Island. Some historical observations, however, may represent misidentifications (Rowell 2012). We now consider it EE based on a lack of recent verified records and expert opinion (King et al. 1997; Hecnar and Hecnar 2004; COSEWIC 2014a). 
LAKE ERIE WATERSNAKE (RE): Previously RE based on observations from three Lake Erie islands, including Pelee Island. Although recent observations exist from six squares (18\%; Table 2), we consider it RE because its contemporary range includes only three or four freshwater islands (COSEWIC 2015), one of which (Middle Island) straddles the boundary line between two squares otherwise dominated by open water.

Smooth Greensnake (Opheodrys vernalis; EE): Previously RE based on single specimens reported from two locations (PPNP, grid 17LG74 and Sandwich West Township, grid 17LG27; Figure 1). Few additional historical records exist (Ontario Nature 2017). We now consider it EE based on a lack of records in over 30 years and substantial search effort at historical locations (Figure 2).

Gray Ratsnake (Pantherophis spiloides; EE): Previously RE based on unconfirmed reports from PPNP and Pelee Island (but see Rowell [2012] for further evidence of historical presence in Essex County). We now consider it EE based on a lack of recent observations and expert opinion (Hecnar and Hecnar 2004; Rowell 2012).

QUEENSNAKE (Regina septemvittata; RE): No previous Essex County status. The first confirmed observation in Essex County did not occur until the mid-1980s (see Oldham 1986).

NORTHERN RIBBONSNAKE (Thamnophis saurita septentrionalis; EE): No previous Essex County status and no recent records (Rowell 2012). The few historical records appear to be data deficient (e.g., King et al. 1997), of questionable validity (e.g., DCL 2009), or conflicting in nature (e.g., records in COSEWIC [2002, 2012] and Ontario Nature [2017]). Regardless, its current or historical presence has been confirmed in many adjacent or nearby counties (i.e., Chatham-Kent [Ontario Nature 2017], Oakland [MIHerpAtlas 2017] and Erie/Ottawa [King et al.1997]), implying a contiguous historical range that included Essex County.

EASTERn SPINy SoftShell (RE): Previously RE and "probably declining" (Oldham 1983), based on observations from PPNP and three other general areas (Pelee Island, Lake St. Clair, and Lake Erie). Still considered $\mathrm{RE}$, however, additional verified reports not included in Table 2 (i.e., not in NHIC database: Hecnar and Hecnar 2004; T. Preney unpubl. data) suggest this species might be widespread.

Spotted Turtle (RE): Previously RE based on known occurrences at four locations. Spotted Turtles have declined from most of their historical Essex County range (Oldham 1983; Hecnar and Hecnar 2004; COSEWIC 2004, 2014b). Recent observations of single animals from three out of five squares (Table 2) may not represent resident populations (i.e., released animals or vagrants: T. Preney unpubl. data), suggesting actual distribution is smaller than reported.

WOODLAND BOX TURTLE (Terrapene carolina caroli$n a$; EE): Previously RE based on observations at four locations. While some authors maintained the possibility of a remnant native population in Essex County (Oldham 1983; King et al. 1997), recent studies suggest that all 20th century observations are the provenance of released pets (COSEWIC 2014c; see below). We consider it EE as per expert opinion (COSEWIC 2014c; COSSARO 2015).

\section{Introduced herpetofauna of Essex County}

Two turtle species are classified as introduced based on recent and historical observations in Essex County and evidence suggesting both can overwinter and reproduce in Ontario.

EASTERN BOX TURTLE (Terrapene carolina): Based on genetic analyses, both subspecies of Eastern Box Turtle have been reported from Essex County: T. $c$. carolina (Woodland Box Turtle; historically native to Ontario, see above) and T. c. triunguis (Three-toed Box Turtle; native to the south-central United States; COSEWIC 2014c). Most Ontario sightings of this species since 1960 have been from Essex County, including $>50$ from PPNP (COSEWIC 2014c). Box turtles can overwinter and reproduce in Ontario (COSEWIC 2014c).

RED-EARED SLIDER (Trachemys scripta elegans): This species has occurred at the OPC since the 1980s (Oldham 1983; Choquette and Valliant 2016) and at other Essex County locations more recently (Browne and Hecnar 2007; Seburn 2015; Ontario Nature 2017). There is circumstantial evidence that Red-eared Sliders can overwinter in Ontario and successful reproduction is suspected (although not yet established; Seburn 2015)

\section{Herpetofaunal richness across Essex County}

Herpetofaunal richness in southern Ontario (Ecoregions 6E and 7E; Armstrong and Dodge 2007) is 47 species/subspecies (excludes nine extirpated, out of range, or non-native species; Ontario Nature 2017). By comparison, contemporary herpetofaunal richness in Essex County is 29 species/subspecies (Table 3), or $62 \%(29 / 47)$ of the southern Ontario species diversity.

The number of recent reptile and amphibian observations submitted per grid square ranged from 1 to 616 $(\overline{\mathrm{x}}=128)$, and the number of species/subspecies reported per grid square (i.e., observed richness) ranged from 1 to $19(\overline{\mathrm{x}}=9)$. Grid squares with the lowest observed species/subspecies richness (1-10) dominate the central-eastern portion of the county and the Lake Erie Islands (outside of Pelee Island; Figure 3). Grid squares with the highest observed species/subspecies richness (11-19) occur in the western half of the county, along the north shore of Lake Erie, and on Pelee Island (Figure 3). Furthermore, the five grid squares with the greatest observed species/subspecies richness overall (1619; Figure 3) are along the western and southern edges of Essex County (17LG28, 17LG27, 17LG35, 17LG75, and 17LG74 in Figure 1). The latter squares include some or all of the following larger natural areas: OPC, 
Detroit River Marshes, Turkey Creek Marshes, Canard River Marshes and Canard River Mouth Marsh, Fighting Island Marsh, Big Creek Marsh, Hillman Marsh, and PPNP (ERCA 2001).

The number of herpetofaunal species/subspecies reported per grid square was positively correlated with number of hectares of natural area per square $(r=0.59$, $n=31, P<0.001)$. Amount of natural area explained a significant, albeit moderate, proportion of variance in observed richness $\left(r^{2}=0.35, F_{1,31}=16.77, P<0.001\right)$. Additional factors, such as uneven sampling effort (i.e., number of observations submitted) per grid square likely influenced observed richness (see Hortal et al. 2007; Pardo et al. 2013), particularly in squares with very low number of observations (e.g., 1-15 observations; Figure 2). As expected, observed richness was also positively correlated with number of recent observations submitted per square $(r=0.68, n=31, P<0.001)$. In order to account for effect of uneven sampling on the relationship between natural area and observed richness, we subsequently incorporated sampling effort and natural area in a multiple linear regression. Both the amount of natural area $(\beta=0.004,95 \% \mathrm{CI}=0.000$ $0.008, P<0.029)$ and number of observations submitted $(\beta=0.013,95 \% \mathrm{CI}=0.006-0.021, P<0.001)$ explained a greater proportion of variance in observed richness per square than natural area alone (adjusted $\left.r^{2}=0.51, F_{2,30}=17.63, P<0.001\right)$.

\section{Status of herpetofauna in Essex County}

Of the 29 species/subspecies of herpetofauna recognized in Essex County, we consider seven (two SAR) to be the most widespread in the region (i.e., recorded from $>18$ squares $[>55 \%]$ ) and six (four SAR) to be the most restricted (i.e., recorded from $\leq 2$ squares $[\leq 6 \%]$; Table 2). Furthermore, almost half $(13 / 29 ; 45 \%)$ of extant herpetofaunal species/subspecies in Essex County are limited in distribution (i.e., RE).

Of the 40 native species/subspecies of herpetofauna recognized from Essex County in the early 1980s, only one $(3 \%)$ was considered extirpated (EE) while 24 (60\%) were considered RE (Oldham 1983). The majority $(70 \%, 28 / 40)$ of herpetofauna have not changed in local status since the early 1980s. Most surprisingly, however, more than a quarter $(11 / 40 ; 28 \%)$ of reptile and amphibian species have declined in status - a decline that is entirely represented by species that went from being considered rare (RE) historically to extirpated (EE) today. Currently, we recognize 42 native species/subspecies of herpetofauna in Essex County, 13 (31\%) of which are now classified EE, with another

TABle 3. An updated checklist of the reptiles and amphibians of Essex County, Ontario. $\mathrm{IN}=$ introduced species, $\mathrm{RE}=$ species considered rare in Essex County, and EE = species considered extirpated from Essex County.

\begin{tabular}{|c|c|}
\hline $\begin{array}{l}\text { AMPHIBIANS (17 species) } \\
\text { FroGS AND TOADS (ANURA) - } 10 \text { species }\end{array}$ & Salamanders (Urodela) -7 species \\
\hline $\begin{array}{l}\text { Blanchard's Cricket Frog (Acris blanchardi) EE } \\
\square \text { Eastern American Toad (Anaxyrus a. americanus) } \\
\square \text { Fowler's Toad (Anaxyrus fowleri) EE } \\
\square \text { Gray Treefrog (Hyla versicolor) EE } \\
\square \text { American Bullfrog (Lithobates catesbeianus) } \\
\square \text { Green Frog (Lithobates clamitans) } \\
\square \text { Northern Leopard Frog (Lithobates pipiens) } \\
\square \text { Wood Frog (Lithobates sylvaticus) EE } \\
\square \text { Spring Peeper (Pseudacris crucifer) } \\
\square \text { Western Chorus Frog (Pseudacris triseriata) }\end{array}$ & $\begin{array}{l}\square \text { Blue-spotted Salamander (Ambystoma laterale) RE } \\
\square \text { Spotted Salamander (Ambystoma maculatum) EE } \\
\square \text { Small-mouthed Salamander (Ambystoma texanum) RE } \\
\square \text { Eastern Tiger Salamander (Ambystoma tigrinum) EE } \\
\square \text { Common Mudpuppy (Necturus m. maculosus) } \\
\square \text { Red-spotted Newt (Notopthalmus v. viridescens) RE } \\
\square \text { Eastern Red-backed Salamander (Plethodon cinereus) RE }\end{array}$ \\
\hline $\begin{array}{l}\text { REPTILES ( } 25 \text { species) } \\
\text { SNAKES AND LIZARDS (SQUAMATA) }-17 \text { species }\end{array}$ & Turtles (Testudines) -8 species $(+2$ introduced species) \\
\hline $\begin{array}{l}\square \text { Blue Racer (Coluber constrictor foxii) RE } \\
\square \text { Timber Rattlesnake (Crotalus horridus) EE } \\
\square \text { Eastern Hog-nosed Snake (Heterodon platirhinos) EE } \\
\square \text { Eastern Milksnake (Lampropeltis triangulum) EE } \\
\square \text { Lake Erie Watersnake (Nerodia sipedon insularum) RE } \\
\square \text { Northern Watersnake (Nerodia s. sipedon) } \\
\square \text { Smooth Greensnake (Opheodrys vernalis) EE } \\
\square \text { Gray Ratsnake (Pantherophis spiloides) EE } \\
\square \text { Eastern Foxsnake (Pantherophis vulpinus) } \\
\square \text { Common Five-lined Skink (Plestiodon fasciatus) RE } \\
\square \text { Queensnake (Regina septemvittata) RE } \\
\square \text { Eastern Massasauga (Sistrurus catenatus) RE } \\
\square \text { Dekay's Brownsnake (Storeria dekayi) } \\
\square \text { Red-bellied Snake (Storeria occipitomaculata) RE } \\
\square \text { Butler's Gartersnake (Thamnophis butleri) } \\
\square \text { Northern Ribbonsnake (T. saurita septentrionalis) EE } \\
\square \text { Eastern Gartersnake (T. s. sirtalis) }\end{array}$ & $\begin{array}{l}\square \text { Eastern Spiny Softshell (Apalone s. spinifera) RE } \\
\square \text { Snapping Turtle (Chelydra serpentina) } \\
\square \text { Midland Painted Turtle (Chrysemys picta marginata) } \\
\square \text { Spotted Turtle (Clemmys guttata) RE } \\
\square \text { Blanding's Turtle (Emydoidea blandingii) } \\
\square \text { Northern Map Turtle (Graptemys geographica) } \\
\square \text { Eastern Musk Turtle (Sternotherus odoratus) RE } \\
\square \text { Woodland Box Turtle (Terrapene c. carolina) EE } \\
\square \text { Eastern Box Turtle (T. c. carolina/T. c. triunguis) IN } \\
\square \text { Red-eared Slider (Trachemys scripta elegans) IN }\end{array}$ \\
\hline
\end{tabular}


13 (31\%) classified as RE. Only one species, Common Mudpuppy (Necturus maculosus maculosus), appears to have improved in status.

\section{Discussion}

With only $6.5 \%$ natural habitat remaining and $80 \%$ of the region in agriculture (ERCA 2002), Essex County provides a natural experiment on the impact of landscape-scale habitat loss on an assemblage of herpetofauna. Our results suggest that almost one third of historically occurring species/subspecies are extirpated, and almost half of those remaining are limited in distribution, impacts that have disproportionately affected salamanders and squamates. Furthermore, nine species of reptiles and amphibians that are not at risk in the province (Gray Treefrog, Wood Frog, Blue-Spotted Salamander [Ambystoma laterale excluding texanumdependant population], Spotted Salamander, Red-spotted Newt [Notopthalmus v. viridescens], Eastern Redbacked Salamander [Plethodon cinereus], Eastern Milksnake, Smooth Greensnake, and Red-bellied Snake [Storeria occipitomaculata]) are either rare or absent here. In southern Ontario, herpetofaunal species richness was positively related to amount of forest cover (amphibians: Hecnar and M'Closkey 1998), and strongly influenced by proximity of nearby populations (PPNP: Hecnar and Hecnar 2005). Also, the number of endangered species found regionally in southern Canada was positively correlated with intensity of agricultural land use (Kerr and Cihlar 2004). Therefore, the large loss and severe fragmentation of amphibian and reptile habitat that has occurred in Essex County, primarily because of intensive agriculture and an extensive concession-style road network, was probably a leading factor in the landscape-scale defaunation of the region.

Grid squares with the highest herpetofaunal species/ subspecies richness (i.e., 17LG27, 17LG28, 17LG35, 17LG74, and 17LG75; Figures 1 and 3) are ideal targets for broad-scale conservation efforts (e.g., habitat restoration and land acquisition), however, not all species are represented in these squares. Of 29 species/ subspecies occurring in Essex County, the maximum number reported from any single square was 19 (Figure 3). Even when species/subspecies richness within the five richest squares is tabulated, only 22 species/ subspecies are represented. Full representation (i.e., 29 species/subspecies) can be maintained by also targetting conservation efforts within five squares of moderately high richness (i.e., 17LG26, 17LG37, 17LG45, 17LG62, and 17LG63) which are collectively occupied by the six RE species with the smallest distributions (Table 2).

A major assumption of this study is that patterns of observed species/subspecies distributions and richness per square are reliable indicators of true patterns. Sampling effort is clearly uneven among squares, and our analysis demonstrated that observed richness was influenced by amount of natural area and number of observations submitted. So how reliable are our interpretations? While we acknowledge that observed distributions and richness do not fully represent their true counterparts, we found that the majority of squares with the lowest sampling effort were also those with the lowest amounts of natural area. Therefore additional search effort in those squares (while increasing observed distributions of locally common species and subsequently increasing observed richness therein) is unlikely to alter observed distributional patterns of RE species or relative patterns of observed species richness. The greatest changes in observed richness would be expected from increased search effort in two squares (17LG36 and 17LG25), as both are characterised by relatively high amounts of natural area, low number of submitted observations, and low observed richness, making them ideal candidates for future surveys.

A declaration of local extirpation generally requires various levels of scrutiny, including date of last observation, knowledge of search effort, generation time, etc. In this study we chose a 20 -year cut-off as a minimum to classify a species as extirpated from the county. It is possible that an amphibian or reptile species could persist in spite of it not being reported in two decades (e.g., Seburn and Mallon 2017). However, in all but three cases (Gray Treefrog, Smooth Greensnake, and Spotted Salamander; none reported in 22-31 years) each EE species was subject to other levels of scrutiny (e.g., detailed species status reports) prior to being considered extirpated.

To prevent future extirpations in Essex County, recovery efforts should target both SAR and common species that are locally rare because provincial ranks alone do not reflect local status in all cases. For example, five locally widespread herpetofauna are listed as SAR provincially, while four RE species are widespread across southern Ontario (Table 2). Regarding SAR, we've identified seven provincially Endangered herpetofauna with small local distributions (i.e., RE; Table 2) and which are arguably at relatively greater risk of extirpation from Essex County (e.g., Massasauga [Sistrurus catenatus] and Queensnake [Regina septemvitatta]) and Canada as a whole (e.g., Blue Racer and Small-mouthed Salamander). Conversely, provincially widespread species such as the Eastern Redbacked Salamander and Red-spotted Newt are locally rare but not SAR in Ontario, therefore a lack of legal protection could result in further declines and extirpations. Six RE species with the most limited local distributions (three salamanders and three snakes; Table 2) are ideal candidates for targetted conservation interventions (e.g., habitat enhancement, threat mitigation, and population management), in order to prevent further biodiversity loss from this herpetologically significant region of Canada. 


\section{Acknowledgements}

We thank three anonymous reviewers for their detailed comments on a previous version of this manuscript, which helped to substantially improve the content. Dr. Daniel W.A. Noble, ARC DECRA Fellow at University of New South Wales, provided advice on statistical analysis (methods and interpretation of results). We thank the Ontario Reptile and Amphibian Atlas for making a vast amount of data available in the public domain and the hundreds of volunteers who have taken the time to submit their observations to those databases. The Ontario Natural Heritage Information Centre (Ontario Ministry of Natural Resources and Forestry) provided provincially tracked occurrence data for Spotted Turtles and Eastern Spiny Softshells in Essex County. Tom Preney, Biodiversity Coordinator for the City of Windsor, provided unpublished data in 2017 on recent observations of Spotted Turtles and Eastern Spiny Softshells in Essex County. Russ Jones, Essex County Field Naturalists' Club, provided unpublished data in 2018 on recent observations of Gray Treefrogs in Essex County. Essex Region Conservation Authority provided the following GIS data layers on natural heritage features: Significant Valley Lands (2008), Conservation Authority Owned/Managed Lands (2016), and Environmentally Significant Areas (1994). Financial assistance for this project was provided by the Government of Ontario (Species at Risk Stewardship Fund). We are indebted to Michael Oldham for his pioneering work on the status and distribution of herpetofauna in Essex County in the early 1980s.

\section{Literature Cited}

Armstrong, D.K., and J.E.P. Dodge. 2007. Paleozoic Geology of Southern Ontario. Miscellaneous Release - Data 219. Project Summary and Technical Document. Sedimentary Geoscience Section, Ontario Geological Survey, Sudbury, Ontario, Canada.

Browne, C.L., and S.J. Hecnar. 2007. Species loss and shifting population structure of freshwater turtles despite habitat protection. Biological Conservation 138: 421-429. https: //doi.org/10.1016/j.biocon.2007.05.008

CHS (Canadian Herpetological Society). 2017. Important Reptile and Amphibian Areas. Accessed 4 October 2018. http://canadianherpetology.ca/conservation/impara.html.

Choquette, J.D., and L. Valliant. 2016. Road mortality of reptiles and other wildlife at the Ojibway Prairie Complex and Greater Park Ecosystem in Southern Ontario. Canadian Field-Naturalist 130: 64-75. https://doi.org/10.22621/cfn. v130i1.1804

COSEWIC (Committee on the Status of Endangered Wildlife in Canada). 2001. COSEWIC assessment and status report on the Timber Rattlesnake Crotalus horridus in Canada. COSEWIC, Ottawa, Ontario, Canada. Accessed 4 October 2018. http://www.registrelep-sararegistry.gc.ca/virtual _sara/files/cosewic/sr_timber_rattlesnake_2001_eng.pdf.

COSEWIC (Committee on the Status of Endangered Wildlife in Canada). 2002. COSEWIC assessment and status report on the Eastern Ribbonsnake Thamnophis sauritus in Canada. COSEWIC, Ottawa, Ontario, Canada. Accessed
4 October 2018. https://www.sararegistry.gc.ca/virtual_sa $\mathrm{ra} /$ files/cosewic/sr_eastern_ribbonsnake_e.pdf.

COSEWIC (Committee on the Status of Endangered Wildlife in Canada). 2004. COSEWIC assessment and update status report on the Spotted Turtle Clemmys guttata in Canada. COSEWIC, Ottawa, Ontario, Canada. Accessed 4 October 2018. https://sararegistry.gc.ca/virtual_sara/files/ cosewic/sr spotted turtle edited e.pdf.

COSEWIC (Committee on the Status of Endangered Wildlife in Canada). 2007. COSEWIC assessment and update status report on the Eastern Hog-nosed Snake Heterodon platirhinos in Canada. COSEWIC, Ottawa, Ontario, Canada. Accessed 4 October 2018. http://www.registrelep-sara registry.gc.ca/virtual_sara/files/cosewic/sr_eastern_hog nosed_snake_0808_e.pdf.

COSEWIC (Committee on the Status of Endangered Wildlife in Canada). 2010a. COSEWIC assessment and status report on the Fowler's Toad Anaxyrus fowleri in Canada. COSEWIC, Ottawa, Ontario, Canada. Accessed 4 October 2018. http://www.registrelep-sararegistry.gc.ca/virtual_sara/ files/cosewic $/ \mathrm{sr} \% 5 \mathrm{FF}$ owler $\% 27 \mathrm{~s} \% 20 \mathrm{Toad} \% 5 \mathrm{~F} 0810 \% \overline{5 \mathrm{Fe}} \%$ 2Epdf.

COSEWIC (Committee on the Status of Endangered Wildlife in Canada). 2010b. COSEWIC assessment and status report on the Butler's Gartersnake Thamnophis butleri in Canada. COSEWIC, Ottawa, Ontario, Canada. Accessed 4 October 2018. https://www.registrelep-sararegistry.gc.ca/ virtual_sara/files/cosewic/sr_butlers_gartersnake_0911_ eng.pdf.

COSEWIC (Committee on the Status of Endangered Wildlife in Canada). 2011. COSEWIC status appraisal summary on the Blanchard's Cricket Frog Acris blanchardi in Canada. COSEWIC, Ottawa, Ontario, Canada. Accessed 4 October 2018. https://www.registrelep-sararegistry.gc.ca/ virtual_sara/files/cosewic/blanchard_cricket_frog_sse_09 11_eng.pdf.

COSEWIC (Committee on the Status of Endangered Wildlife in Canada). 2012. COSEWIC assessment and status report on the Eastern Ribbonsnake Thamnophis sauritus in Canada. COSEWIC, Ottawa, Ontario, Canada. Accessed 4 October 2018. https://wildlife-species.canada.ca/speciesrisk-registry/virtual_sara/files/cosewic/sr_coulevre_mnc_ e_ribbonsnake_111 $\overline{3}$ _e.pdf.

COSEWIC (Committee on the Status of Endangered Wildlife in Canada). 2014a. COSEWIC assessment and status report on the Eastern Milksnake Lampropeltis triangulum in Canada. COSEWIC, Ottawa, Ontario, Canada. Accessed 4 October 2018. https://sararegistry.gc.ca/virtual_sara/files/ cosewic/sr_Eastern Milksnake_2014_e.pdf.

COSEWIC (Committee on the Status of Endangered Wildlife in Canada). 2014b. COSEWIC assessment and status report on the Spotted Turtle Clemmys guttata in Canada. COSEWIC. Ottawa, Ontario, Canada. Accessed 4 October 2018. https://sararegistry.gc.ca/virtual_sara/files/cosewic/ sr_Spotted Turtle_2014_e.pdf.

COSEWIC (Committee on the Status of Endangered Wildlife in Canada). 2014c. COSEWIC assessment and status report on the Eastern Box Turtle Terrapene carolina in Canada. COSEWIC, Ottawa, Ontario, Canada. Accessed 4 October 2018. http://www.sararegistry.gc.ca/virtual sara/ files/cosewic/sr_Eastern Box Turtle_2014_e.pdf.

COSEWIC (Committee on the Status of Endangered Wildlife in Canada). 2015. COSEWIC assessment and update status report on the Lake Erie Watersnake Nerodia sipedon insularum in Canada. COSEWIC, Ottawa, Ontario, Cana- 
da. Accessed 4 October 2018. http://www.sararegistry.gc. ca/virtual_sara/files/cosewic/sr_Lake Erie Watersnake_20 15 e.pdf.

COSEWIC (Committee on the Status of Endangered Wildlife in Canada). 2016. COSEWIC assessment and status report on the Spiny Softshell Apalone spinifera in Canada. COSEWIC, Ottawa, Ontario, Canada. Accessed 4 October 2018. http://www.sararegistry.gc.ca/virtual_sara/files/cose wic/sr_Spiny Softshell_2016_e.pdf.

COSSARO (Committee on the Status of Species at Risk in Ontario). 2011a. COSSARO candidate species at risk evaluation for Blanchard's Cricket Frog (Acris blanchardi). Ontario Government Documents, Toronto, Ontario, Canada. Accessed 4 October 2018. http://www.ontla.on.ca/lib rary/repository/mon/26004/316820.pdf.

COSSARO (Committee on the Status of Species at Risk in Ontario). 2011b. COSSARO candidate species at risk evaluation for Timber Rattlesnake (Crotalus horridus). Ontario Government Documents, Toronto, Ontario, Canada. Accessed 4 October 2018. http://www.ontla.on.ca/lib rary/repository/mon/26004/317141.pdf.

COSSARO (Committee on the Status of Species at Risk in Ontario). 2015. COSSARO candidate species at risk evaluation for Eastern Box Turtle (Terrapene carolina). Ontario Government Documents, Toronto, Ontario, Canada. Accessed 4 October 2018. http://cossaroagency.ca/wpcontent/uploads/2017/06/Accessible_COSSARO-evaluat ion-Eastern-box-turtle.pdf.

Craig, J.M., D.A. Mifsud, A.S. Briggs, J. Boase, and G. Kennedy. 2015. Mudpuppy (Necturus maculosus maculosus) spatial distribution, breeding water depth, and use of artificial spawning habitat in the Detroit River. Herpetological Conservation and Biology 10: 926-934.

Crother, B.I. 2017. Scientific and Standard English Names of Amphibians and Reptiles of North America North of Mexico, with Comments Regarding Confidence in our Understanding. Eighth Edition. Society for the Study of Amphibians and Reptiles Herpetological Circular 43.

Dance, K.W., and C.A. Campbell. 1981. Eastern hognose snake sighted at Point Pelee National Park, Ontario. Ontario Field Biologist 35: 40-42.

DCL (Dillon Consulting Ltd.). 2009. Wildlife investigations re. species at risk Matchette/Sprucewood commercial development site Windsor, ON. Report for Wood Bull, LLP Barristers and Solicitors, Toronto, Ontario, Canada.

EL (Ecologistics Ltd.). 1976. Windsor Airport environmental study. Report for Transport Canada, Ottawa, Ontario, Canada.

Environment Canada. 2010. Recovery strategy for the Timber Rattlesnake (Crotalus horridus) in Canada. Species at Risk Act Recovery Strategy Series. Environment Canada, Ottawa, Ontario, Canada. Accessed 5 October 2018. https: //www.registrelep-sararegistry.gc.ca/virtual_sara/files/plans /rs_timber_rattlesnake_final_0310_e.pdf.

ERCĀ (Essex Region Conservation Authority). 2001. Natural areas map of Essex Region. Essex Region Conservation Authority, Essex, Ontario, Canada.

ERCA (Essex Region Conservation Authority). 2002. Essex Region biodiversity conservation strategy - habitat restoration and enhancement guidelines. ERCA, Essex, Ontario, Canada.

Gardner-Costa, J., T. Preney, and D. Zhao. 2014. Ojibway Prairie Bioblitz 2014: summary report for partners. Ojibway Nature Centre, Windsor, Ontario, Canada. Accessed 5 October 2018. http://www.essexcountynature.com/wp-
content/uploads/2018/03/Ojibway-Prairie-BioBlitz-2014Report_revisedv2.pdf.

Government of Ontario. 2005. Provincial policy statement. Ministry of Municipal Affairs and Housing, Toronto, Ontario, Canada.

Government of Ontario. 2018. Species at risk in Ontario. Accessed 5 October 2018. https://www.ontario.ca/environ ment-and-energy/species-risk-ontario-list.

Hecnar, S.J., and D.R. Hecnar. 2004. Losses of amphibians and reptiles at Point Pelee National Park. Pages 127-139 in Parks and Protected Areas Research in Ontario: Planning Northern Parks and Protected Areas. Edited by C. Rehbein, G. Nelson, T. Beechey, and R. Payne. Proceedings of the Parks Research Forum of Ontario AGM, 4-6 May 2004, Lakehead University, Parks Research Forum of Ontario, University of Waterloo, Waterloo, Ontario, Canada.

Hecnar, S.J., and D.R. Hecnar. 2005. Feasibility of repatriation of extirpated herpetofauna to Point Pelee National Park. Final Report of Memorandum of Understanding CR 02-51. Department of Biology, Lakehead University, Thunder Bay, Ontario, Canada.

Hecnar, S.J., and R.T. M'Closkey. 1998. Species richness patterns of amphibians in southwestern Ontario ponds. Journal of Biogeography 25: 763-772. https://doi.org/10. 1046/j.1365-2699.1998.2540763.x

Hortal, J., J.M. Lobo, and A. Jiménez-Valverde. 2007. Limitations of biodiversity databases: case study on seed-plant diversity in Tenerife, Canary Islands. Conservation Biology 21: 853-863. https://doi.org/10.1111/j.1523-1739.2007.006 $86 . x$

IUCN (International Union for Conservation of Nature). 2012. Guidelines for application of IUCN Red List criteria at regional and national levels: version 4.0. IUCN, Gland, Switzerland and Cambridge, United Kingdom. Accessed 5 October 2018. http://s3.amazonaws.com/iucnredlist-new cms/staging/public/attachments/3101/reg_guidelines_en. pdf.

Jalava, J.V., J.D. Ambrose, and N.S. May. 2009. National Recovery Strategy for Carolinian woodlands and associated species at risk: phase I. Draft 11. Carolinian Canada Coalition and Ontario Ministry of Natural Resources, London, Ontario, Canada.

King, R.B., M.J. Oldham, W.F. Weller, and D. Wynn. 1997. Historic and current amphibian and reptile distributions in the island region of western Lake Erie. American Midland Naturalist 138: 153-173. https://doi.org/10.2307/2426663

Livo, L.J., G.A. Hammerson, and H.M. Smith. 1998. Summary of Amphibians and Reptiles Introduced into Colorado. Northwestern Naturalist 79: 1-11. https://doi.org/ $10.2307 / 3536811$

MIHerpAtlas. 2017. Michigan Herp Atlas: a statewide herpetological atlas and data hub. Accessed 5 October 2018. http://www.miherpatlas.org.

NHIC (Natural Heritage Information Centre). 2017. Provincially tracked species and observation data. ESRI File geodatabase. Data provided by Ontario Ministry of Natural Resources. Queen's Printer, Toronto, Ontario, Canada.

NatureServe. 2017. NatureServe Explorer: an online encyclopedia of life [web application]. Version 7.1. NatureServe, Arlington, Virginia, USA. Accessed 3 May 2018. http://ex plorer.natureserve.org.

Ngo, A., V.L. McKay, and R.W. Murphy. 2009. Recovery Strategy for Tiger Salamander (Ambystoma tigrinum) (Great Lakes Population) in Canada. Species at Risk Act Recovery Strategy Series. Parks Canada Agency, Ottawa, Ontario, 
Canada. Accessed 5 October 2018. https://registrelep-sara registry.gc.ca/virtual_sara/files/plans/rs_tiger_salaman der great lakes 0409 e.pdf.

Oldham, M.J. 1983. Environmentally significant areas of the Essex Region. A Background Report to the Essex Region Conservation Plan. Essex Region Conservation Authority, Essex, Ontario, Canada.

Oldham, M.J. 1984a. A preliminary list of the amphibians of Essex County. Canadian Amphibian and Reptile Conservation Society Bulletin 21(5): 1-6.

Oldham, M.J. 1984b. A preliminary list of the reptiles of Essex County. Canadian Amphibian and Reptile Conservation Society Bulletin 22: 1-8.

Oldham, M.J. 1986. The queen snake, a reptile new to Essex County. The Egret 3(3): 25-26.

Oldham, M.J. 1988. Ontario herpetofaunal summary 1985. World Wildlife Fund Canada, Toronto; Essex Region Conservation Authority, Essex; and Ontario Ministry of Natural Resources, Southwestern Region, London, Ontario, Canada.

Oldham, M.J., and D.A. Sutherland. 1986. 1984 Ontario herpetofaunal summary. Essex Region Conservation Authority, Essex and World Wildlife Fund, Toronto, Ontario, Canada.

Ontario Nature. 2015. ORAA infographic. Accessed 5 October 2018. https:/ontarionature.org/wp-content/uploads/2017/ 11/ON_Nature_Spring-2015_Ontario_Reptile_and_Am phibian Atlas infographic.pdf.

Ontario Nature. 2017. Reptiles and amphibians of Ontario - interactive map. Accessed 5 October 2018. https://ontarionature.org/oraa/maps.

Ontario Nature. 2018. Reptiles and amphibians of Ontario - interactive map. Accessed 5 October 2018. https://ontarionature.org/oraa/maps.
Pardo, I., M.P. Pata, D. Gómez, and M.B. García. 2013. A novel method to handle the effect of uneven sampling effort in biodiversity databases. PLoS One 8: e52786. https: //doi.org/10.1371/journal.pone.0052786

Planck, R.J., and J.T. Planck. 1977. Ecology and status of the Butler's garter snake, Thamnophis butleri (Cope), in southwestern Ontario. Department of Supply and Services, Toronto, Ontario, Canada.

Pulfer, T. 2014. Thirty years of tracking herps. ON Nature 1: 7.

Rowell, J. 2012. The Snakes of Ontario: Natural History, Distribution and Status. Art Bookbindery, Winnipeg, Manitoba, Canada.

Seburn, D.C. 2015. Distribution of the exotic Pond Slider (Trachemys scripta) in Ontario. Canadian Field-Naturalist 129: 342-348. https://doi.org/10.22621/cfn.v129i4.1756

Seburn, D.C., and E. Mallon. 2017. Has the Eastern Redbacked Salamander (Plethodon cinereus) declined in Ontario? Canadian Field-Naturalist 131: 115-119. https:// doi.org/10.22621/cfn.v131i2.1981

Town of LaSalle. 2016. Town of LaSalle Official Plan. 5 January 2015 Office Consolidation. Corporation of the Town of LaSalle, LaSalle, Ontario, Canada.

Tozer, D.C. 2016. The state of marsh birds and frogs: Nottawasaga Valley-Lake Simcoe watershed report 1995-2015. Bird Studies Canada, Port Rowan, Ontario, Canada. Accessed 5 October 2018. https://www.birdscanada.org/download/ GLMMPWatershedrpt.pdf.

Weller, W.F., and M.J. Oldham. 1988. Ontario herpetofaunal summary: 1986. Ontario Field Herpetologists, Cambridge, Ontario, Canada.

Received 28 February 2018

Accepted 7 May 2018 